\title{
Assessment of a Practical Method for Identifying Anovular Dairy Cows Synchronized for First Postpartum Timed Artificial Insemination
}

\author{
E. Silva, R. A. Sterry, and P. M. Fricke ${ }^{1}$ \\ Department of Dairy Science, University of Wisconsin-Madison, Madison 53706
}

\begin{abstract}
Our objective was to determine whether a single examination of ovaries using transrectal ultrasonography at the first GnRH injection of a Presynch + Ovsynch protocol is a useful method for assessing cyclicity status and thereby enabling differential management of anovular vs. cyclic cows. Lactating Holstein cows $(\mathrm{n}=842)$ receiving a Presynch + Ovsynch protocol to initiate first postpartum timed artificial insemination (TAI) were used to compare 2 methods for assessing cyclicity status before TAI. For the standard method (using RIA), blood samples were collected at the second $\mathrm{PGF}_{2 \alpha}$ injection of Presynch and the first GnRH injection of Ovsynch, and cows with serum progesterone $\geq 1.0 \mathrm{ng} / \mathrm{mL}$ in one or both samples were classified as cycling, whereas cows with serum progesterone $<1.0 \mathrm{ng} / \mathrm{mL}$ in both samples were classified as anovular. For the practical method, transrectal ultrasonography (U/S) was used to determine the presence or absence of a corpus luteum (CL) at the first GnRH injection of Ovsynch, and cows without CL were classified as anovular, whereas cows with CL were classified as cycling. Statistical agreement (kappa) between the RIA and U/S methods to identify cycling cows was 0.66 . Sensitivity, specificity, positive predictive value, and negative predictive value of U/S to identify anovular status were $85.7,87.7,64.7$, and 95.9\%, respectively. We conclude that assessing the presence or absence of CL at the first GnRH injection of a Presynch + Ovsynch protocol using U/S is a reliable and practical method for identifying the cyclicity status of cows before first TAI, but may slightly overestimate the proportion of anovular cows compared with the RIA method.
\end{abstract}

Key words: dairy cow, anovular, ultrasound

\section{INTRODUCTION}

Recent large field trials have reported that 20 to $30 \%$ of high-producing lactating Holstein cows are anovular

Received November 21, 2006.

Accepted March 13, 2007.

${ }^{1}$ Corresponding author: pmfricke@wisc.edu at 60 to 75 DIM (Gümen et al., 2003; Lopez et al., 2005; Sterry et al., 2006), a time coinciding with the end of the voluntary waiting period and onset of AI to detected estrus or timed AI (TAI) after synchronization of ovulation in many herds. For studies in which anovular cows were retrospectively identified after synchronization of ovulation and TAI, anovular cows had reduced fertility and greater pregnancy loss than their cycling herdmates (Santos et al., 2004a,b; Sterry et al., 2006). Anovular cows, therefore, represent a significant proportion of cows at the end of the voluntary waiting period that have poor reproductive performance after synchronization of ovulation and TAI. Treatment of anovular cows with GnRH 5 d after TAI improved fertility for anovular but not for cycling cows (Sterry et al., 2006). Practical implementation of such a treatment or others that may be developed to resolve the anovular condition before or after TAI may be best achieved by identifying and targeting the anovular cows that may benefit from treatment rather than treating all cows.

Identification of anovular cows using a variety of methods has been reported in the scientific literature. Cartmill et al. (2001) reported that $16.2 \%$ of cows were anovular using 3 blood samples collected 7 and $5 \mathrm{~d}$ apart before initiation of Ovsynch (synchronization regimen using sequential injections of $\mathrm{GnRH}$ and $\mathrm{PGF}_{2 \alpha}$ to precisely time ovulation for TAI), whereas Gümen et al. (2003) used 2 consecutive weekly ultrasound (U/S) examinations and blood samples to detect the presence of luteal tissue and serum progesterone $\left(\mathbf{P}_{4}\right)$ and reported that $20.2 \%$ of cows were anovular. Another frequently reported method is to assess serum $\mathrm{P}_{4}$ from blood samples collected 10 to $14 \mathrm{~d}$ apart before or during a hormonal protocol for synchronization of ovulation and TAI (Cordoba and Fricke, 2002; Cerri et al., 2004; Stevenson et al., 2006) with the rationale that cycling cows should have serum $\mathrm{P}_{4} \geq 1 \mathrm{ng} / \mathrm{mL}$ at one or both of these serum samples, whereas anovular cows would have serum $\mathrm{P}_{4}$ $<1 \mathrm{ng} / \mathrm{mL}$ in both serum samples.

Presynchronization protocols (Presynch; postpartum regimen using 2 injections of $\mathrm{PGF}_{2 \alpha}$ administered 14 $\mathrm{d}$ apart to synchronize estrous cycles before applying Ovsynch) have been used to manipulate the reproduc- 
tive cycle so that cows are in the mid-luteal phase of the estrous cycle at initiation of Ovsynch, thereby increasing fertility to TAI (Moreira et al., 2001; Navanukraw et al., 2004). Cycling cows receiving a Presynch + Ovsynch protocol for first postpartum TAI should have an ultrasonographically detectable CL at the first GnRH injection of Ovsynch, whereas anovular cows would not. Presynchronization increased the proportion of cows with greater $\mathrm{P}_{4}(\geq 1.0 \mathrm{ng} / \mathrm{mL})$ at the second $\mathrm{PGF}_{2 \alpha}$ injection of Presynch and the first GnRH injection of Ovsynch (60.0 vs. $52.0 \%$ and 72.0 vs. $59.0 \%$, respectively; El-Zarkouny et al., 2004). Indeed, $26 \%$ of cows submitted for first postpartum TAI using Presynch + Ovsynch were classified as anovular based on the absence of a detectable CL by U/S at the first GnRH injection of Presynch + Ovsynch (Sterry et al., 2006); however, this method has not been compared with other published methods for identifying anovular cows.

Our objective was to determine the accuracy of using the presence or absence of a CL based on a single U/S examination of ovaries at the first $\mathrm{GnRH}$ injection of a Presynch + Ovsynch protocol compared with a published method using serum $\mathrm{P}_{4}$ profiles from 2 blood samples collected $12 \mathrm{~d}$ apart. Our hypothesis was that the U/S method would be a practical and accurate method for identifying anovular cows under field conditions compared with more intensive blood sampling and RIA technique.

\section{MATERIALS AND METHODS}

\section{Animals}

Lactating Holstein dairy cows on a commercial dairy farm of approximately 1,600 lactating cows located in south-central Wisconsin were enrolled into this study from January to October, 2005. Cows were housed in free-stall barns and were fed a TMR with ad libitum access to feed and water. All cows received bST (Posilac, $500 \mathrm{mg}$, Monsanto Co., St. Louis, MO) beginning 57 to $71 \mathrm{~d}$ postpartum and continuing every $14 \mathrm{~d}$ throughout the study. Cows were allocated weekly to breeding groups to receive a Presynch protocol using 2 injections of $\mathrm{PGF}_{2 \alpha}$ (Lutalyse, $25 \mathrm{mg}$ i.m., Pfizer Animal Health, New York, NY) administered $14 \mathrm{~d}$ apart (39 \pm 3 and 53 $\pm 3 \mathrm{~d}$ postpartum). Ovsynch was initiated $12 \mathrm{~d}$ after the second $\mathrm{PGF}_{2 \alpha}$ injection of Presynch as follows: GnRH (Cystorelin, $100 \mu \mathrm{g}$ i.m., Merial, Duluth, GA) $65 \pm 3 \mathrm{~d}$ postpartum; $\mathrm{PGF}_{2 \alpha}, 72 \pm 3 \mathrm{~d}$ postpartum; GnRH $54 \mathrm{~h}$ after $\mathrm{PGF}_{2 \alpha}$. All cows received TAI approximately $16 \mathrm{~h}$ after the second GnRH injection of Ovsynch.

Cows were enrolled into the experiment weekly beginning $53 \pm 3 \mathrm{~d}$ postpartum on the day of the second $\mathrm{PGF}_{2 \alpha}$ injection of the Presynch + Ovsynch protocol. A total of 891 lactating Holstein cows were initially enrolled into the experiment, with 842 of these cows included in the final analysis ( 28 cows did not receive the correct hormone injections during Presynch + Ovsynch or were sold or died, and 21 cows had one or more missing blood samples). Body condition score ( 1 = emaciated and 5 = obese; Wildman et al., 1982) was evaluated by the same individual throughout the study at the time of enrollment, and cows with a BCS $\leq 2.0$ ( $\mathrm{n}=13$ cows) were not enrolled into the study based on breeding criteria set by the farm manager.

\section{Collection and Processing of Serum Samples}

Blood samples were collected via venipuncture of the median caudal vein or artery into evacuated tubes (Vacutainer; BD, Franklin Lakes, NJ). Blood samples were allowed to clot for $12 \mathrm{~h}$ at $4^{\circ} \mathrm{C}$, centrifuged $(1,935 \times g$ for $15 \mathrm{~min}$ ), and serum was harvested and stored at $-20^{\circ} \mathrm{C}$ until assayed for $\mathrm{P}_{4}$ concentration using a solidphase, no-extraction RIA (Coat-a-Count, Diagnostic Products Cooperation, Los Angeles, CA). Interassay and intraassay coefficients of variation were 10.8 and $8.9 \%$ and 2.0 and $6.2 \%$ for low $(2.0 \mathrm{ng} / \mathrm{mL})$ and high $(10.0 \mathrm{ng} / \mathrm{mL})$ quality control samples, respectively.

\section{Determination of Cyclicity Status}

Two methods were compared to assess cyclicity status before first postpartum TAI. For the standard method (RIA), blood samples were collected at the second $\mathrm{PGF}_{2 \alpha}$ injection of Presynch and at the first $\mathrm{GnRH}$ injection of Ovsynch (Figure 1). Cows with serum $\mathrm{P}_{4} \geq 1.0 \mathrm{ng} / \mathrm{mL}$ in one or both serum samples were classified as cycling, whereas cows with serum $\mathrm{P}_{4}<1.0 \mathrm{ng} / \mathrm{mL}$ in both samples were classified as anovular as described previously (Moreira et al., 2001; Stevenson et al., 2006).

For the practical method (U/S), transrectal ultrasonography was conducted using a portable scanner (Easi-scan, BCF Technology Ltd., Livingston, UK) fitted with a 7.5-MHz linear-array transducer and a video display headset to determine the presence or absence of a CL at the first GnRH injection of the Presynch + Ovsynch protocol (Figure 1). Ultrasonography examinations were performed by the same veterinarian, who had $2 \mathrm{yr}$ of experience using U/S. During each examination, cows within individual pens were restrained in feedline headlocks for a maximum of $2 \mathrm{~h}$. A CL was defined as being present when an echogenic structure with a line of demarcation visible between the CL and the ovarian stroma was visualized (Lean et al., 1992). The diameter of the visualized corpus luteum was estimated using an image of the apparent maximal diameter of the structure using on-screen background gridlines comprising squares with $10-\mathrm{mm}$ sides as described previously (Rivera et al., 2006). 


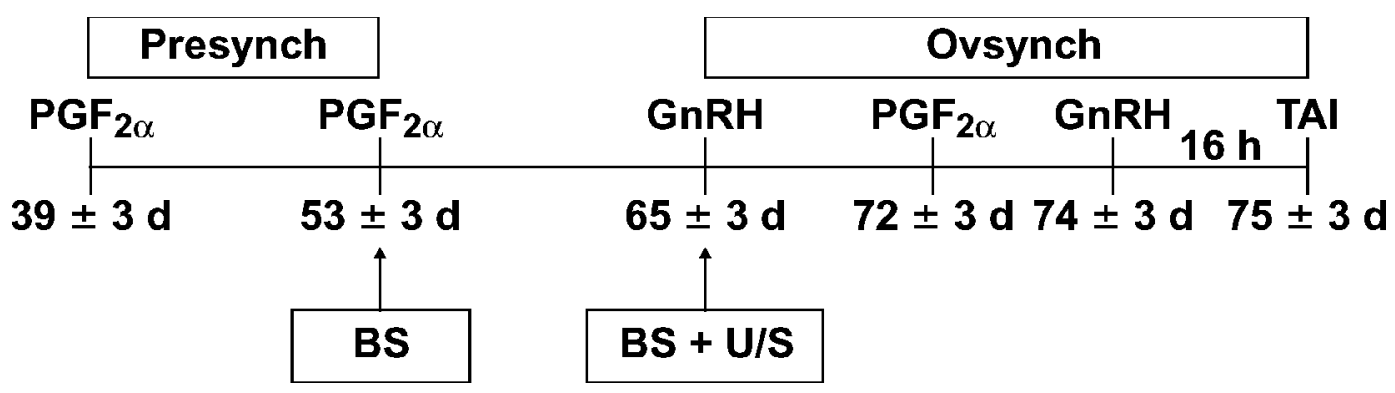

Figure 1. Diagram of blood sampling (BS) and transrectal ultrasound (U/S) examinations during the Presynch + Ovsynch protocol. All cows were presynchronized with 2 injections of $\mathrm{PGF}_{2 \alpha}$ (39 $\pm 3 \mathrm{~d}$ and $53 \pm 3 \mathrm{~d}$ postpartum), and the first GnRH injection of Ovsynch was initiated $12 \mathrm{~d}$ later ( $65 \pm 3 \mathrm{~d}$ postpartum). Blood samples were collected $53 \pm 3 \mathrm{~d}$ and $65 \pm 3 \mathrm{~d}$ postpartum and an ultrasound examination was performed $65 \pm 3 \mathrm{~d}$ postpartum. TAI = timed AI.

Cycling cows subjected to a Presynch + Ovsynch protocol for first postpartum TAI should have an ultrasonically detectable CL at the first GnRH injection of Ovsynch $12 \mathrm{~d}$ after the second $\mathrm{PGF}_{2 \alpha}$ injection of Presynch, whereas anovular cows should not. Accordingly, for the U/S method, cows without a detectable CL at the first GnRH injection of Presynch + Ovsynch were classified as anovular, whereas cows in which a CL was detected were classified as cycling.

To further assess the accuracy of using U/S to determine functional luteal status, the presence of a CL based on U/S was compared with the presence of a functional CL based on serum $\mathrm{P}_{4}$ in a blood sample collected at the U/S examination. Cows with serum $\mathrm{P}_{4}$ $\geq 1.0 \mathrm{ng} / \mathrm{mL}$ were classified as having a functional CL present, whereas cows with serum $\mathrm{P}_{4}<1.0 \mathrm{ng} / \mathrm{mL}$ were classified as lacking a functional CL as described previously (Rivera et al., 2005).

\section{Statistical Analyses}

The kappa statistic of PROC FREQ (SAS Institute, 1999) was used to determine agreement between U/S and RIA to determine cyclicity status (Martin et al., 1987; Noordhuizen et al., 2001). Kappa is a measure of repeatability in which a value of 1 indicates perfect agreement, and 0 indicates the level of agreement expected to occur by chance alone. In the comparison of tests, a kappa value of 0.4 to 0.5 indicates a moderate level of agreement, 0.5 to 0.6 indicates good agreement, and $>0.6$ indicates a high level of agreement (Martin et al., 1987).

A $2 \times 2$ contingency table was constructed to determine the sensitivity, specificity, positive predictive value (PPV), and negative predictive value (NPV) of the U/S method to detect anovular cows (Martin et al., 1987; Table 1). Although the "true" cyclicity status of cows in the study was not established (i.e., the RIA method may result in errors), the $\mathrm{P}_{4}$ concentration de- termined by RIA was used as the gold standard to determine cyclicity status of cows for assessing the U/S method. Sensitivity was calculated as the proportion of anovular cows that were correctly classified by U/S (number of true anovular cows/number of true anovular cows + number of false cycling cows), and the PPV was the proportion of all cows classified anovular by U/S that truly were anovular (number of true anovular cows/number of true anovular cows + number of false anovular cows). Specificity was the proportion of cycling cows correctly classified by U/S (number of true cycling

Table 1. Contingency table comparing 2 methods (ultrasound vs. RIA) to assess cyclicity status and to detect the presence or absence of a functional corpus luteum (CL) in lactating Holstein cows synchronized to receive first postpartum timed $\mathrm{AI}^{1}$

\begin{tabular}{lccc}
\hline \multirow{2}{*}{$\begin{array}{l}\text { Ultrasound } \\
\text { outcome }^{2}\end{array}$} & \multicolumn{2}{c}{ RIA classification $^{3}$} & \\
\cline { 2 - 3 } & Anovular & Cycling & Total \\
\hline Anovular & 150 & 82 & 232 \\
Cycling & 25 & 585 & 610 \\
Total & 175 & 667 & 842 \\
& No functional CL & Functional CL & Total \\
\cline { 2 - 2 } CL not detected & 197 & 35 & 232 \\
CL detected & 53 & 557 & 610 \\
Total & 250 & 592 & 842 \\
\hline
\end{tabular}

${ }^{1}$ Cows received a Presynch + Ovsynch protocol using injections of $\mathrm{PGF}_{2 \alpha}(\mathrm{PGF} ; 25 \mathrm{mg})$ and $\mathrm{GnRH}(\mathrm{G} ; 100 \mu \mathrm{g})$ to initiate first postpartum timed $\mathrm{AI}$ (TAI) as follows: PGF ( $39 \pm 3$ and $53 \pm 3 \mathrm{~d}$ postpartum); G (65 \pm 3 d postpartum); PGF (72 \pm 3 d postpartum); G (74 $\pm 3 \mathrm{~d}$ postpartum) + TAI 16 h later.

${ }^{2}$ Transrectal ultrasonography of ovaries was used to determine the presence or absence of a CL at the first GnRH injection of Ovsynch. Cows without CL were classified as anovular, whereas cows with CL were classified as cycling.

${ }^{3}$ Blood samples were collected at the second $\mathrm{PGF}_{2 \alpha}$ injection of Presynch and at the first GnRH injection of Ovsynch to determine progesterone $\left(\mathrm{P}_{4}\right)$ concentration by RIA. Cows with serum $\mathrm{P}_{4} \geq 1.0 \mathrm{ng} /$ $\mathrm{mL}$ in one or both samples were classified as cycling, whereas cows with serum $\mathrm{P}_{4}<1.0 \mathrm{ng} / \mathrm{mL}$ in both samples were classified as anovular. Cows with serum $\mathrm{P}_{4} \geq 1.0 \mathrm{ng} / \mathrm{mL}$ were classified as having a functional CL present, whereas cows with serum $\mathrm{P}_{4}<1.0 \mathrm{ng} / \mathrm{mL}$ were classified as lacking a functional CL. 
cows/number of true cycling cows + number of false anovular cows), and NPV was the proportion of all cows classified cycling that truly were cycling (number of true cycling cows/number of true cycling cows + number of false cycling cows). A similar $2 \times 2$ contingency table was constructed to determine sensitivity, specificity, PPV, and NPV to estimate the presence of a functional CL. Sensitivity, specificity, PPV, and NPV calculations were performed using Win Episcope 2.0 (Thrusfield et al., 2001).

PROC GLIMMIX (SAS Institute, 1999) was used to analyze the effect of method (U/S vs. RIA) and the interactions between method and parity (primiparous vs. multiparous) and method and BCS on anovular status. Least squares means were calculated and used for comparisons, and cows were included in the repeated statement. The model was run separately for parity and BCS because of missing BCS values for several cows $(n=4)$. Differences in fertility (pregnancies per AI) for cows classified as cycling vs. anovular using the RIA and U/ $S$ methods were compared by $\chi^{2}$ analysis using the PROC FREQ statistic of SAS (SAS Institute, 2003). Regression analyses were performed to determine the best fitted line between percentage of anovular cows and BCS using PROC REG in SAS (SAS Institute, 2003). Treatment differences with $P<0.05$ were considered significant, and differences between $P>0.05$ and $P<0.15$ were considered statistical tendencies.

\section{RESULTS AND DISCUSSION}

\section{Assessment of Cyclicity Status}

In the present study, statistical agreement (kappa) between RIA and U/S to identify cyclicity status was $0.66(95 \%$ confidence interval $=0.60$ to 0.71$)$ indicating a high level of agreement between the methods (Martin et al., 1987). The prevalence of cows classified as anovular differed $(P<0.01)$ by method and was $27.6 \%(232 /$ 842 ) for U/S and $20.8 \%$ (175/842) for RIA. There was an interaction between method and parity $(P<0.01)$ in which a greater proportion of primiparous than multiparous cows were anovular based on the RIA method and a tendency for a greater proportion of primiparous cows to be classified anovular based on the U/S method (Table 2). These data agree with those from other studies in which primiparous cows have a greater (Moreira et al., 2001; Gümen et al., 2003; Santos et al., 2004a) or a tendency to have (El-Zarkouny et al., 2004) a greater proportion of anovular cows than multiparous cows. Similar to previous reports (Santos et al., 2004a,b; Sterry et al., 2006), fertility of cows classified as anovu$\operatorname{lar}[30.9 \%(69 / 223)$ and $31.4 \%$ (53/169) for anovular cows based on U/S and RIA methods, respectively] in the present study was lower $(P<0.01) 27 \mathrm{~d}$ after TAI
Table 2. Effect of parity and method of detection on the proportion (\%) of lactating Holstein cows classified as anovular by ultrasound or RIA before first postpartum timed AI after Presynch + Ovsynch $^{1}$

\begin{tabular}{lcc}
\hline Parity & Ultrasound & RIA \\
\hline Primiparous & $31.9^{\mathrm{A}}$ & $28.3^{\mathrm{a}}$ \\
& $(98 / 307)$ & $(87 / 307)$ \\
Multiparous & $25.1^{\mathrm{B}}$ & $16.5^{\mathrm{b}}$ \\
& $(134 / 535)$ & $(88 / 535)$ \\
\hline
\end{tabular}

A,B Proportions with different superscripts tended to differ $(P<0.15)$ by parity.

${ }^{\mathrm{a}, \mathrm{b}}$ Proportions with different superscripts differed $(P<0.01)$ by parity.

${ }^{1}$ For the first method, transrectal ultrasonography was used to determine the presence or absence of a corpus luteum (CL) at the first GnRH injection of Ovsynch. Cows without CL were classified as anovular, whereas cows with CL were classified as cycling. For the second method, blood samples were collected at the second $\mathrm{PGF}_{2 \alpha}$ injection of Presynch and at the first GnRH injection of Ovsynch to determine progesterone $\left(\mathrm{P}_{4}\right)$ concentration by RIA. Cows with serum $\mathrm{P}_{4} \geq 1.0 \mathrm{ng} / \mathrm{mL}$ in one or both samples were classified as cycling, whereas cows with serum $\mathrm{P}_{4}<1.0 \mathrm{ng} / \mathrm{mL}$ in both samples were classified as anovular.

than that of their cycling herdmates $[52.5 \%(315 / 600)$ and $50.6 \%$ (331/654) for cycling cows based on U/S and RIA methods, respectively]; however, fertility was similar for anovular vs. cycling cows between the classification methods.

Because prevalence of a disease or physiologic state influences the predictive value of a test (Noordhuizen et al., 2001), these parameters were calculated separately for primiparous and multiparous cows. Positive predictive value was lower for multiparous than for primiparous cows (Table 3) and may be related to the lower prevalence of anovular cows in the multiparous group. If a disease or physiologic state has low prevalence in a population at risk, the PPV will depend on the specificity of the test (Noordhuizen et al., 2001).

The overall sensitivity, specificity, PPV, and NPV of U/S to identify anovular cows were 85.7, 87.7, 64.7, and $95.9 \%$, respectively (Table 3 ). A minor source of disagreement between RIA and U/S to determine cyclicity status occurred because 3\% (25/842) of the cows with serum $\mathrm{P}_{4}<1.0 \mathrm{ng} / \mathrm{mL}$ in both serum samples (i.e., anovular by RIA) were classified as having a CL present at the first GnRH injection of Ovsynch (i.e., cycling by $\mathrm{U} / \mathrm{S})$. Among these 25 cows, $50 \%$ had a $\mathrm{CL} \leq 10 \mathrm{~mm}$, and the average $\mathrm{P}_{4}$ concentration for these cows was $0.30 \pm 0.05 \mathrm{ng} / \mathrm{mL}$. It is possible that these cows were undergoing luteal regression at the time of assessment using ultrasound. Although ultrasonographic assessment of $C L$ is a viable alternative to determine circulating $\mathrm{P}_{4}$ concentrations, luteal tissue regresses at a slower rate than the decrease in plasma $\mathrm{P}_{4}$ concentration during luteal regression (Kastelic et al., 1990). Furthermore, the RIA method used to determine cyclicity status 
Table 3. Sensitivity, specificity, positive predictive value (PPV), negative predictive value (NPV), and accuracy of using transrectal ultrasound (U/S) to classify anovular cows and to detect the presence of a functional corpus luteum (CL)

\begin{tabular}{lccccc}
\hline Item & $\begin{array}{c}\text { Sensitivity } \\
(\%)\end{array}$ & $\begin{array}{c}\text { Specificity }^{2} \\
(\%)\end{array}$ & $\begin{array}{c}\mathrm{PPV}^{3} \\
(\%)\end{array}$ & $\begin{array}{c}\mathrm{NPV}^{4} \\
(\%)\end{array}$ & $\begin{array}{c}\text { Accuracy }^{5} \\
(\%)\end{array}$ \\
\hline Anovular & & & & & \\
Overall & 85.7 & 87.7 & 64.7 & 95.9 & 87.3 \\
& $(150 / 175)$ & $(585 / 667)$ & $(150 / 232)$ & $(585 / 610)$ & $(735 / 842)$ \\
Primiparous & 85.06 & 89.1 & 75.5 & 93.8 & 87.9 \\
& $(74 / 87)$ & $(196 / 220)$ & $(74 / 98)$ & $(196 / 209)$ & $(270 / 307)$ \\
Multiparous & 86.4 & 87.0 & 56.7 & 97.0 & 86.9 \\
& $(76 / 88)$ & $(389 / 447)$ & $(76 / 134)$ & $(389 / 401)$ & $(465 / 535)$ \\
Functional CL ${ }^{7}$ & 94.1 & 78.8 & 91.3 & 84.9 & 89.5 \\
& $(557 / 592)$ & $(197 / 250)$ & $(557 / 610)$ & $(197 / 232)$ & $(754 / 842)$ \\
\hline
\end{tabular}

\footnotetext{
${ }^{1}$ Proportion of anovular cows or cows with a functional CL detected using U/S.

${ }^{2}$ Proportion of cycling cows or cows lacking a CL detected using U/S.

${ }^{3}$ Proportion of anovular cows based on U/S that were classified as anovular based on RIA or cows identified with a CL using U/S with progesterone $\left(\mathrm{P}_{4}\right) \geq 1.0 \mathrm{ng} / \mathrm{mL}$ using RIA.

${ }^{4}$ Proportion of cycling cows based on U/S that were classified as cycling based on RIA or cows lacking a CL based on U/S that had $\mathrm{P}_{4}<1.0 \mathrm{ng} / \mathrm{mL}$ based on RIA.

${ }^{5}$ Proportion of correctly identified cyclicity status and functional status of CL using U/S.

${ }^{6}$ Cows lacking a CL at the first GnRH of Ovsynch + Presynch were classified as anovular, whereas cows with a CL were classified as cycling using U/S. Blood samples were collected at the second $\mathrm{PGF}_{2 \alpha}$ injection of Presynch and at the first $\mathrm{GnRH}$ injection of Ovsynch to determine $\mathrm{P}_{4}$ concentration by RIA. Cows with serum $\mathrm{P}_{4} \geq 1.0 \mathrm{ng} / \mathrm{mL}$ in one or both samples were classified as cycling, whereas cows with serum $\mathrm{P}_{4}<1.0$ $\mathrm{ng} / \mathrm{mL}$ in both samples were classified as anovular.

${ }^{7}$ Cows with serum $\mathrm{P}_{4} \geq 1.0 \mathrm{ng} / \mathrm{mL}$ were classified as having a functional CL present, whereas cows with serum $\mathrm{P}_{4}<1.0 \mathrm{ng} / \mathrm{mL}$ were classified as not having a functional CL.
}

in this and other studies may not be as accurate as more intensive methods that incorporate a combination of more frequent and sequential U/S and RIA for $\mathrm{P}_{4}$ (Wiltbank et al., 2002).

To assess the use of a 1.0-ng/mL cutoff point for serum $\mathrm{P}_{4}$ using the RIA method, sensitivity, specificity, PPV, NPV, prevalence, and accuracy of U/S compared with RIA outcomes were calculated using various cutoff points. Varying the $\mathrm{P}_{4}$ cutoff point used to assess anovular cows for the RIA method from 0.5 to 1.0 to $1.2 \mathrm{ng} /$ $\mathrm{mL}$ resulted in similar values for sensitivity, specificity, PPV, NPV, true prevalence, and accuracy of the U/S method, whereas increasing the cutoff point to $\geq 1.5 \mathrm{ng} /$ $\mathrm{mL}$ resulted in a gradual decrease in sensitivity, NPV, and accuracy (Table 4).

The major source of disagreement between RIA and U/S to determine cyclicity status occurred because 79.3 (184/232), 5.6 (13/232), and 15.0\% (35/232) of cows without a CL based on U/S had serum $\mathrm{P}_{4}$ concentrations of $<0.5,0.5$ to $<1.0$, and $\geq 1.0 \mathrm{ng} / \mathrm{mL}$, respectively, at the U/S examination. The 35 cows with $\mathrm{P}_{4} \geq 1.0 \mathrm{ng} / \mathrm{mL}$ at the first GnRH injection of Ovsynch (i.e., cycling based on RIA) and lacking a CL at this time based on U/S were classified as anovular using U/S; the mean $\mathrm{P}_{4}$ concentration for these cows was $3.3 \pm 0.3 \mathrm{ng} / \mathrm{mL}$. In addition, 75 (9.0\% of all cows) cows had serum $\mathrm{P}_{4} \geq 1.0$ $\mathrm{ng} / \mathrm{mL}$ at the second $\mathrm{PGF}_{2 \alpha}$ injection of Presynch and $<1.0 \mathrm{ng} / \mathrm{mL}$ at the first $\mathrm{GnRH}$ injection of Ovsynch (i.e., cycling based on RIA), and 47 (5.6\% of all cows) of these cows had no CL at the first GnRH injection of Ovsynch (i.e., anovular based on U/S). Although a variety of physiologic scenarios could explain these discrepancies, we cannot determine the exact source of disagreement in each case, and at least some of this disagreement is likely due to technical error in interpreting the U/S examinations. Most important, although the U/S method used in the present study to determine cyclicity status slightly overestimated the proportion of anovular cows compared with the RIA method, all but 25 anovular cows based on the RIA method were identified using the U/S method (Table 1). Because most anovular cows based on the RIA method were identified as such using the U/S method, the use of U/S to identify anovular cows under field conditions may allow for targeted treatments to resolve the anovular condition before TAI, thereby improving reproductive performance. If an effective strategy for treating anovular cows were to be developed, it would be advantageous to slightly overestimate rather than underestimate the anovular condition and fail to apply treatment to cows that may otherwise benefit from it.

Another consideration for the disagreement between U/S and RIA was that cows with ovarian cysts were considered anovular using U/S in the present study. Fluid-filled cystic structures $\geq 25 \mathrm{~mm}$ in diameter identified at the scanning session conducted at the time of 
Table 4. Sensitivity, specificity, positive predictive value (PPV), negative predictive value (NPV), and true prevalence of anovular cows for the ultrasound method based on various progesterone concentration cutoff points used for assessing anovular cows for the RIA method ${ }^{1}$

\begin{tabular}{lccccccc}
\hline & \multicolumn{7}{c}{$\mathrm{P}_{4}$ cutoff value $(\mathrm{ng} / \mathrm{mL})$} \\
\cline { 2 - 8 } Item & 0.5 & 1.0 & 1.2 & 1.5 & 2.0 & 2.5 & 3.0 \\
\hline Sensitivity (\%) & 88.2 & 85.7 & 82.9 & 78.4 & 76.8 & 70.2 & 62.4 \\
Specificity (\%) & 86.8 & 87.7 & 88.2 & 88.2 & 88.9 & 89.0 & 89.7 \\
PPV (\%) & 61.2 & 64.7 & 66.8 & 67.2 & 69.8 & 71.1 & 75.0 \\
NPV (\%) & 96.9 & 95.9 & 94.8 & 93.0 & 92.0 & 88.5 & 82.8 \\
True prevalence (\%) & 19.1 & 20.8 & 22.2 & 23.6 & 25.1 & 28.0 & 33.1 \\
Accuracy (\%) & 87.0 & 87.3 & 87.0 & 85.9 & 85.9 & 83.7 & 80.6 \\
\hline
\end{tabular}

\begin{abstract}
${ }^{1}$ For the ultrasound method, cows lacking a CL at the first GnRH of Ovsynch + Presynch were classified as anovular, whereas cows with a CL were classified as cycling. For the RIA method, blood samples were collected at the second $\mathrm{PGF}_{2 \alpha}$ injection of Presynch and at the first $\mathrm{GnRH}$ injection of Ovsynch to determine progesterone $\left(\mathrm{P}_{4}\right)$ concentration by RIA. Cows with serum $\mathrm{P}_{4}$ equal to or greater than the given cutoff values in one or both samples were classified as cycling, whereas cows with serum $\mathrm{P}_{4}$ less than the given cutoff values in both samples were classified as anovular.
\end{abstract}

the second GnRH injection were classified as ovarian cysts based on ultrasonographic morphology (Fricke and Wiltbank, 1999). No attempt was made to further classify cystic structures as follicular, luteal, or benign based on ultrasonographic morphology. When luteal cysts were differentiated from follicular cysts based on $\mathrm{P}_{4}$ concentrations $>0.5 \mathrm{ng} / \mathrm{mL}$, mean $\mathrm{P}_{4}$ concentration was $1.6 \pm 0.1 \mathrm{ng} / \mathrm{mL}$ (Farin et al., 1990), whereas when the cutoff point to determine luteal cysts was $0.9 \mathrm{ng} /$ $\mathrm{mL}$, mean $\mathrm{P}_{4}$ concentrations were $3.6 \pm 0.5$ to $3.9 \pm 0.6$ $\mathrm{ng} / \mathrm{mL}$ (Ribadu et al., 1994; Douthwaite and Dobson, 2000). Thus, cystic cows lacking a CL and having high $\mathrm{P}_{4}$ may have reduced the sensitivity of the U/S method to identify anovular cows in the present study.

Based on the $\mathrm{P}_{4}$ concentrations at the second $\mathrm{PGF}_{2 \alpha}$ injection of Presynch and the first $\mathrm{GnRH}$ injection of Ovsynch (high, $\geq 1.0 \mathrm{ng} / \mathrm{mL}$; low, $<1.0 \mathrm{ng} / \mathrm{mL}$ ), cows were classified into high-high, high-low, low-high, and lowlow groups resulting in a distribution of $55.3(466 / 842)$, 8.9 (75/842), 15.0 (126/842), and 20.8\% (175/842), respectively. The mean $\mathrm{P}_{4}$ concentration for anovular cows identified using the RIA method was $0.08 \pm 0.01$ $\mathrm{ng} / \mathrm{mL}$ at the second $\mathrm{PGF}_{2 \alpha}$ injection of Presynch and $0.10 \pm 0.01 \mathrm{ng} / \mathrm{mL}$ at the first $\mathrm{GnRH}$ injection of Ovsynch compared with a mean $\mathrm{P}_{4}$ concentration of 1.20 $\pm 0.12 \mathrm{ng} / \mathrm{mL}$ at the second $\mathrm{PGF}_{2 \alpha}$ injection and $0.60 \pm$ $0.08 \mathrm{ng} / \mathrm{mL}$ at the first $\mathrm{GnRH}$ injection of Ovsynch for anovular cows identified using the U/S method.

\section{Assessment of Luteal Status}

In the present study, statistical agreement (kappa) between the presence or absence of a CL using U/S and serum $\mathrm{P}_{4}$ concentration at the U/S examination was $0.74(95 \%$ confidence interval $=0.69$ to 0.79$)$ indicating a high level of agreement between the methods (Martin et al., 1987). Sensitivity, specificity, PPV, and NPV of using U/S to assess the presence of a CL were 94.1, $78.8,91.3,84.9 \%$, respectively (Table 3 ). Our results agree with previous studies reporting a kappa agreement between U/S and plasma $\mathrm{P}_{4}$ concentration to detect CL of 0.71 and 0.74 (Battocchio et al., 1999; McDougall and Rhodes, 1999). Another study reported a kappa value $>0.75$ among skilled U/S operators, and a kappa value of $>0.9$ between an experienced operator and ovarian dissection to determine the presence of CL (Lean et al., 1992). Pierson and Ginther (1987) reported $100 \%$ agreement between ultrasound and ovarian dissection for identification of the presence of a CL in Holstein heifers.

\section{Anovular Cows by BCS}

The proportion of anovular cows submitted for TAI is of concern because fertility is reduced and pregnancy loss is greater for anovular cows submitted for TAI compared with cycling herdmates (Gümen et al., 2003; Santos et al., 2004b; Stevenson et al., 2006). An inverse relationship between BCS and cyclicity status has been reported in which cows with the lowest BCS have the greatest proportion of anovular cows (Moreira et al., 2001; Gümen et al., 2003; Santos et al., 2004a). Moreover, studies reported that cows with lower BCS $(\leq 2.5)$ have reduced fertility after Ovsynch and TAI (Moreira et al., 2000; Souza, 2005). Based on logistical regression analysis of BCS categories, both methods yielded a similar proportion of anovular cows except for cows with a BCS of 3.00 in which the proportion of anovular cows was greater $(P<0.01)$ for the U/S method compared with the RIA method (Figure 2). Based on a linear regression analysis of these data, a quadratic effect was fitted in which the proportion of anovular cows decreased as BCS increased up to 3.25 and then increased. This increase after a BCS of 3.25 was based 


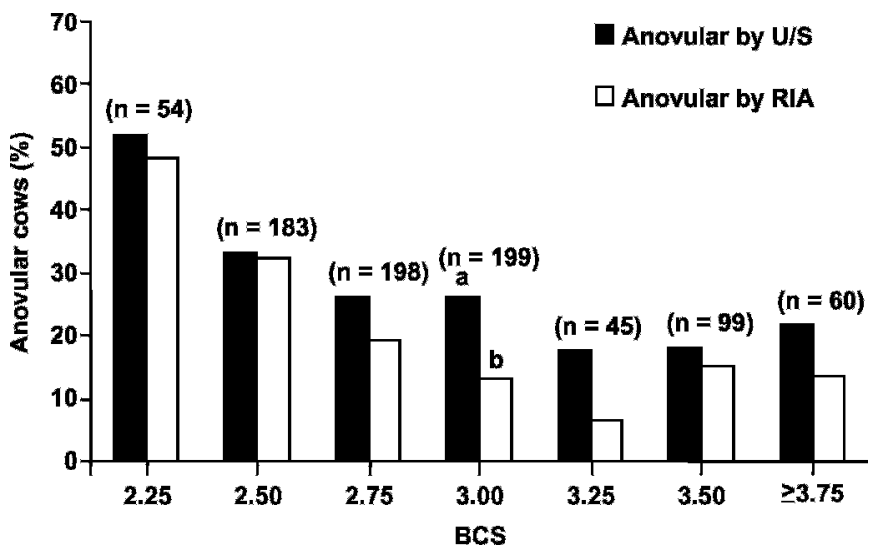

Figure 2. Percentage of anovular cows by BCS evaluated at the second $\mathrm{PGF}_{2 \alpha}$ injection of Presynch. The statistical analysis was performed using PROC GLIMMIX (SAS Institute, 1999). Within a BCS category, proportions with different letters differ $(P<0.01)$.

on the derivatives of the quadratic equations. For the $\mathrm{U} / \mathrm{S}$ method, the $\mathrm{R}^{2}=0.95$ and $\mathrm{R}_{\text {adj }}^{2}=0.92(\mathrm{y}=301.5-$ $\left.168.1 \mathrm{x}+24.9 \mathrm{x}^{2} ; P<0.01\right)$, whereas for the RIA method, $\mathrm{R}^{2}=0.97$ and $\mathrm{R}_{\text {adj }}^{2}=0.95\left(\mathrm{y}=381.8-224.5 \mathrm{x}+33.8 \mathrm{x}^{2}\right.$; $P<0.01$ ), where y $=$ percentage of cows not cycling and $\mathrm{x}=$ BCS. Despite this relationship, only $38.4 \%$ of all cows classified as anovular using the U/S method and $48.6 \%$ of all cows classified as anovular using the RIA method had a $\mathrm{BCS} \leq 2.5$ at the second $\mathrm{PGF}_{2 \alpha}$ injection of Presynch. Indeed, the majority of cows classified anovular $(61.6 \%$ using the U/S method and $51.4 \%$ using the RIA method) in the present study had a BCS $>2.5$ at the second $\mathrm{PGF}_{2 \alpha}$ injection of Presynch. Thus, physiologic conditions other than BCS must play a role in determining cyclicity status of lactating dairy cows (Wiltbank et al., 2002). From a practical perspective, identification of anovular cows based on the criterion of low BCS alone would be an ineffective strategy for identifying and treating anovular cows before first postpartum TAI.

\section{CONCLUSIONS}

We conclude that assessing the presence or absence of $\mathrm{CL}$ at the first GnRH injection of a Presynch + Ovsynch protocol using U/S is a reliable and practical method for identifying cyclicity status of cows before first TAI but may slightly overestimate the proportion of anovular cows compared with RIA. Nonetheless, because nearly all anovular cows based on the RIA method were identified as such using the U/S method, use of U/S to identify anovular cows under field conditions may allow for targeted treatments to resolve the anovular condition before TAI, thus improving reproductive performance.

\section{ACKNOWLEDGMENT}

The authors thank Blue Star Dairy (De Forest, WI) and their staff for the use of their cows and facilities for this study and Jerry Guenther and Diego Calderon for their technical assistance and expertise.

\section{REFERENCES}

Battocchio, M., G. Gabai, A. Mollo, M. C. Veronesi, F. Soldano, G. Bono, and F. Cairoli. 1999. Agreement between ultrasonographic classification of the CL and plasma progesterone concentration in dairy cows. Theriogenology 51:1059-1069.

Cartmill, J. A., S. Z. El-Zarkouny, B. A. Hensley, G. C. Lamb, and J. S. Stevenson. 2001. Stage of cycle, incidence, and timing of ovulation, and pregnancy rates in dairy cattle after three timed breeding protocols. J. Dairy Sci. 84:1051-1059.

Cerri, R. L. A., J. E. P. Santos, S. O. Juchem, K. N. Galvão, and R. C. Chebel. 2004. Timed artificial insemination with estradiol cypionate or insemination at estrus in high-producing dairy cows. J. Dairy Sci. 87:3704-3715.

Cordoba, M. C., and P. M. Fricke. 2002. Initiation of the breeding season in a grazing-based dairy by synchronization of ovulation. J. Dairy Sci. 85:1752-1763.

Douthwaite, R., and H. Dobson. 2000. Comparison of different methods of diagnosis of cystic ovarian disease in cattle and an assessment of its treatment with a progesterone-releasing intravaginal device. Vet. Rec. 147:355-359.

El-Zarkouny, S. Z., J. A. Cartmill, B. A. Hensley, and J. S. Stevenson. 2004. Pregnancy in dairy cows after synchronized ovulation regimens with or without presynchronization and progesterone. J. Dairy Sci. 87:1024-1037.

Farin, P. W., R. S. Youngquist, J. R. Parfet, and H. A. Garverick. 1990. Diagnoses of luteal and follicular ovarian cysts in dairy cows by sector scan ultrasonography. Theriogenology 34:633-642.

Fricke, P. M., and M. C. Wiltbank. 1999. Effect of milk production on the incidence of double ovulation in dairy cows. Theriogenology $52: 1133-1143$.

Gümen, A., J. N. Guenther, and M. C. Wiltbank. 2003. Follicular size and response to ovsynch versus detection of estrus in anovular and ovular lactating dairy cows. J. Dairy Sci. 86:3184-3194.

Kastelic, J. P., D. R. Bergfelt, and O. J. Ginther. 1990. Relationship between ultrasonic assessment of the corpus luteum and plasma progesterone concentration in heifers. Theriogenology 33:12691278.

Lean, I. J., N. Abe, S. Duggan, and N. Kingsford. 1992. Within and between observer agreement on ultrasonic evaluation of bovine ovarian structures. Aust. Vet. J. 69:279-282.

Lopez, H., D. Z. Caraviello, L. D. Satter, P. M. Fricke, and M. C. Wiltbank. 2005. Relationship between level of milk production and multiple ovulations in lactating dairy cows. J. Dairy Sci. 88:2783-2793.

Martin, S. W., A. H. Meek, and P. Willeberg. 1987. Measurement of disease frequency and production. Pages $63-75$ in Veterinary Epidemiology, Principles and Methods. 1st ed. Iowa State University Press, Ames.

McDougall, S., and F. M. Rhodes. 1999. Detection of a corpus luteum in apparently anoestrus cows by manual palpation, transrectal ultrasonography and plasma progesterone concentration. N.Z. Vet. J. 47:47-52.

Moreira, F., C. Risco, M. F. A. Pires, J. D. Ambrose, M. Drost, M. DeLorenzo, and W. W. Thatcher. 2000. Effect of body condition on reproductive efficiency of lactating dairy cows receiving a timed insemination. Theriogenology 53:1305-1319.

Moreira, F., C. Orlandi, C. A. Risco, R. Mattos, F. Lopes, and W. W. Thatcher. 2001. Effect of presynchronization and bovine somatotropin on pregnancy rates to a timed artificial insemination protocol in lactating dairy cows. J. Dairy Sci. 84:1646-1659.

Navanukraw, C., D. A. Redmer, L. P. Reynolds, J. D. Kirsch, A. T. Grazul-Bilska, and P. M. Fricke. 2004. A modified presynchroni- 
zation protocol improves fertility to timed artificial insemination in lactating dairy cows. J. Dairy Sci. 87:1551-1557.

Noordhuizen, J. P. T. M., K. Frankena, M. V. Thrusfield, and E. A. Graat. 2001. Application of quantitative methods in veterinary epidemiology. 2nd ed. Wageningen Pers, Wageningen, the Netherlands.

Pierson, R. A., and O. J. Ginther. 1987. Reliability of diagnostic ultrasonography for identification and measurement of follicles and detecting the corpus luteum in heifers. Theriogenology 28:929936.

Ribadu, A. Y., W. R. Ward, and H. Dobson. 1994. Comparative evaluation of ovarian structures in cattle by palpation per rectum, ultrasonography and plasma progesterone concentration. Vet. Rec. 135:452-457.

Rivera, H., H. Lopez, and P. M. Fricke. 2005. Use of intravaginal progesterone-releasing inserts in a synchronization protocol before timed $\mathrm{AI}$ and for synchronizing return to estrus in Holstein heifers. J. Dairy Sci. 88:957-968.

Rivera, H., R. A. Sterry, and P. M. Fricke. 2006. Presynchronization with gonadotropin-releasing hormone does not improve fertility in Holstein heifers. J. Dairy Sci. 89:3810-3816.

Santos, J. E. P., S. O. Juchem, R. L. A. Cerri, K. N. Galvão, R. C. Chebel, W. W. Thatcher, C. S. Dei, and C. R. Bilby. 2004a. Effect of bST and reproductive management on reproductive performance of Holstein dairy cows. J. Dairy Sci. 87:868-881.
Santos, J. E. P., W. W. Thatcher, R. C. Chebel, R. L. A. Cerri, and K. N. Galvão. 2004b. The effect of embryonic death rates in cattle on the efficacy of estrus synchronization programs. Anim. Reprod. Sci. 82-83:513-535.

SAS Institute. 1999. SAS OnlineDoc. Version 8. SAS Institute Inc., Cary, NC.

Souza, A. H. 2005. Effect of estradiol-17 b supplementation before the last GnRH of the Ovsynch protocol in high producing dairy cows. Chapter 3. MS thesis. University of Wisconsin-Madison.

Sterry, R. A., M. L. Welle, and P. M. Fricke. 2006. Treatment with gonadotropin-releasing hormone after first timed AI improves fertility in noncycling lactating dairy cows. J. Dairy Sci. 89:4237-4245.

Stevenson, J. S., J. R. Pursley, H. A. Garverick, P. M. Fricke, D. J. Kesler, J. S. Ottobre, and M. C. Wiltbank. 2006. Treatment of cycling and noncycling lactating dairy cows with progesterone during Ovsynch. J. Dairy Sci. 89:2567-2578.

Thrusfield, M., C. Ortega, I. de Blas, J. P. Noordhuizen, and K. Frankena. 2001. Win Episcope 2.0: Improved epidemiological software for veterinary medicine. Vet. Rec. 148:567-572.

Wildman, E. E., G. M. Jones, P. E. Wagner, R. L. Boman, H. F. Troutt, and T. N. Lesch. 1982. A dairy cow body condition scoring system and its relationship to selected production characteristics. J. Dairy Sci. 65:495-501.

Wiltbank, M. C., A. Gümen, and R. Sartori. 2002. Physiological classification of anovulatory conditions in cattle. Theriogenology $57: 21-52$. 